\title{
Krisis Sebagai Akselerator Layanan Komunikasi Instansi Publik Di Masa Pandemi
}

\author{
Anna Farianingrum1, $S$ Bekti Istiyanto² \\ 1Fakultas Ilmu Sosial dan Ilmu Politik Universitas Jenderal Soedirman \\ Email:anna.farianingrum@mhs.unsoed.ac.id \\ 2Fakultas Ilmu Sosial dan Ilmu Politik Universitas Jenderal Soedirman \\ Email: bekti.istiyanto@unsoed.ac.id
}

\begin{abstract}
ABSTRAK
Virus Corona Disease (Covid-19) menjadi pandemi yang melanda sejumlah negara, hal ini berdampak pada beberapa sektor serta menyebabkan permasalahan di bidang kesehatan, ekonomi, sosial, pendidikan, dan komunikasi. Dengan adanya pandemi ini telah membuat beberapa negara melakukan strategi dengan menerapkan kebijakan di antaranya melakukan lockdown dan memberlakukan pembatasan mobilitas warganya, hal ini menyebabkan terganggunya kegiatan ekonomi dan layanan kepada masyarakat. Berbagai kebijakan dilakukan, baik oleh pemerintah maupun korporasi guna meningkatkan layanan kepada masyarakat dalam penerapan new normal. Pandemi Covid-19 mengakibatkan banyak tenaga kerja yang harus mengalami Pemutusan Hubungan Kerja (PHK). Dalam situasi seperti ini, perusahaan harus mampu beradaptasi dan membuat strategi sebagai upaya untuk pemecahan masalah, hal ini juga berlaku di BPJS Ketenagakerjaan. Penelitian ini bertujuan untuk mengetahui dan memahami strategi komunikasi krisis korporasi dan bagaimana pengelolaan media digital yang dilakukan oleh BPJS Ketenagakerjaan dan perannya terhadap pelayanan. Metode penelitian ini menggunakan pendekatan kualitatif deskriptif. Pengumpulan data diperoleh dengan wawancara, studi pustaka, website dan dokumentasi. Penelitian ini menunjukan hasil bahwa BPJS Ketenagakerjaan dalam merespon krisis telah membuat tahapan berupa penguatan kinerja tim, membuat inovasi dalam menghadapi krisis dan berkomitmen untuk memberikan pelayanan prima kepada peserta melalui sebuah aplikasi media digital yang disebut LAPAK ASIK.
\end{abstract}

Kata Kunci: Covid-19, Krisis, BPJS Ketenagakerjaan, LAPAK ASIK

\begin{abstract}
The Corona Virus Disease (Covid-19) has become a pandemic that has hit a number of countries, this has an impact on several sectors and causes problems in the fields of health, economy, social, education, and communication. This pandemic has forced many countries to lock down or restrict the mobility of their citizens, causing disruption of economic activities and public services. Various policies were carried out by both the government and corporations in order to improve services to the community in implementing the new normal. One of the impacts of this pandemic is that many workers have had to experience layoffs. In this situation the company must be able to adapt and make strategies as an effort to solve problems, this also applies to BPJS Ketenagakerjaan. This study aims to determine the corporate crisis communication strategy and how digital media management is carried out by BPJS Ketenagakerjaan and its role in service. This research method used is a descriptive qualitative approach. Data collection from this research was obtained by interview, literature study, website and documentation. This study shows the results that BPJS Ketenagakerjaan in responding to the crisis has made stages in the form of strengthening team performance, making innovations in dealing with crises and being committed to providing excellent service to participants through a digital media application called LAPAK ASIK.
\end{abstract}

Keywords: Covid-19, Crisis, BPJS Employment, LAPAK ASIK 


\section{PENDAHULUAN}

Coronavirus Disease (Covid-19) ditemukan pertama kali di Kota Wuhan, China pada akhir Desember 2019 (Yunus \& Rezki, 2020) telah melanda beberapa negara di belahan dunia dan hal ini berdampak serius terhadap beberapa sektor tatanan kehidupan yang ada di masyarakat, antara lain: kesehatan, ekonomi, sosial, pendidikan, komunikasi dan lain sebagianya. Dengan adanya pandemi, membuat banyak negara melakukan beberapa strategi dan mengambil kebijakan.

Pandemi ini memberikan dampak besar kepada perusahaan yang bergerak di bidang jasa pelayanan. Agar proses bisnis tetap berjalan, maka perusahaan perlu melakukan upaya untuk merespon dan mencari solusi dari dampak yang ditimbulkan oleh pandemi Covid-19, mengingat pandemi ini masih berlangsung dan belum dapat diperkirakan sampai kapan berakhirnya. Untuk itu, dibutuhkan penanganan yang sesuai dan tepat di tengah kondisi yang sedang melanda.

Kondisi buruk yang tidak tertangani dapat menjadi krisis, yaitu suatu peristiwa yang tidak terduga sebelumnya dan dampak yang ditimbulkan mengakibatkan kerugian baik terhadap citra, reputasi, dan mengancam kredibilitas (Cangara, 2017). Masalah pandemi dan dampaknya berimbas juga kepada BPJS Ketenagakerjaan, akibat situasi ini pelayanan dan operasional di BPJS Ketenagakerjaan kepada masyarakat terganjal, karena harus melakukan social distancing. Selain itu dampak dari pandemi Covid-19 mengakibatkan banyaknya pekerja yang harus mengalami Pemutusan Hubungan Kerja (PHK). Dengan adanya Pandemi Covid 19 yang berkepanjangan menyebabkan banyaknya perusahaan bangkrut dan tenaga kerja di PHK sehingga mereka sudah tidak lagi memiliki penghasilan, akhirnya tenaga kerja tersebut berbondong - bondong datang ke BPJS Ketenagakerjaan hendak mengambil tabungan Jaminan Hari Tua (JHT).

Menurut catatan BPJS Ketenagakerjaan dikemukakan oleh Deputi Direktur bidang Hubungan Masyarakat BP Jamsostek (Maulana \& A Leony, 2020), per akhir September 2020, sudah ada 270.095 orang yang mengklaim JHT atau meningkat 44 persen secara tahunan (yearon-year). Nilai klaim tersebut mencapai Rp 3,4 triliun. Sepanjang Januari- September 2020, klaim JHT sudah mencapai 1,98 juta kasus. Angka ini naik 22,22 persen dibandingkan dengan periode yang sama pada tahun sebelumnya yang besarnya 1,62 juta kasus. Pada sembilan bulan pertama 2020 tersebut, nilai pencairan JHT mencapai Rp 24,5 triliun. Nilai pencairan ini meningkat 26,28 persen dibanding periode yang sama 2019 sebesar Rp19,4 triliun. Imbas gelombang PHK ini tak hanya berdampak pada peningkatan klaim JHT.

Sesuai dengan kebijakan pemerintah untuk memutus rantai penyebaran Covid 19 diberlakukan social distancing (Gitiyarko, 2020), sehingga pengambilan tabungan Jaminan Hari Tua (JHT) secara manual atau tatap muka dan berkerumun tidak dapat lagi dilakukan. Dengan adanya PHK besar-besaran atau tsunami PHK membuat tenaga kerja menuju Kantor BPJS Ketenagakerjaan untuk mengambil JHT, ini merupakan permasalahan serius karena dapat menyebabkan kerumunan dan menjadi risiko penularan Covid 19.

Hal tersebut di atas yang menurut peneliti sangat menarik untuk diteliti karena situasi krisis pandemi Covid-19 belum pernah terjadi dan masih berlangsung sampai saat ini. Masalah yang ingin peneliti sampaikan adalah dengan adanya permasalahan ini, maka dibutuhkan terobosan, yaitu sebuah bentuk layanan yang dilakukan oleh BPJS Ketenagakerjaan selaku institusi pelayanan publik agar tetap mampu memberikan pelayanan secara optimal.

\section{TINJAUAN PUSTAKA}

\section{Pelayanan Prima}

Pelayanan prima menurut Priharto (2020) adalah suatu cara dalam memberikan pelayanan yang baik dengan manajemen modern dan mengutamakan kepuasan pelanggan. Pelayanan Prima menuntut seseorang untuk melayani secara maksimal sehingga didapatkan pelayanan yang terbaik.

Pelayanan prima atau excellent service adalah pelayanan yang diberikan melebihi dari apa 
yang diharapkan oleh pelanggan dengan memberikan kualitas layanan yang cepat, aman, nyaman, biaya terjangkau, proses mudah, dan memberikan kepuasan (Suyanto \& Sutopo, 2006).

\section{BPJS Ketenagakerjaan}

BPJS Ketenagakerjaan (Badan Penyelenggara Jaminan Sosial Ketenagakerjaan) adalah Badan hukum publik yang bertanggung jawab langsung kepada Presiden Republik Indonesia dan diberi wewenang oleh negara untuk memberikan perlindungan bagi tenaga kerja yang mengalami risiko sosial terkait hubungan kerja. BPJS Ketenagakerjaan merupakan pelaksana "UU Jaminan Sosial Tenaga Kerja (Jamsostek)", sesuai dengan UU No. 24 tahun 2011. BPJS Ketenagakerjaan menyelenggarakan 4 program, yaitu Program Jaminan Kecelakaan Kerja (JKK), Jaminan Kematian (JKM), Jaminan Hari Tua ( JHT) ), Jaminan Sosial Pensiun (JP). Dan mulai Juni 2021 ditambah dengan 1 program yaitu Jaminan Kehilangan Pekerjaan (JKP).

BPJAMSOSTEK memiliki alat kontrol dalam mengukur hubungan antara BPJAMSOSTEK dengan pesertanya tentang su pelanggan yaitu aplikasi e-Survey dan kanal aduan Whistle Blowing System (WBS). Whistleblowing system yang efektif, transparan dan bertanggung jawab dapat mengurangi risiko yang dihadapi organisasi, akibat dari adaya pelanggaran baik dari segi keuangan, operasi, hukum, keselamatan kerja, dan reputasi dari organisasi tersebut (Suyadi \& Sunarti, 2016).

\section{Krisis}

Dalam literatur (Ardianto, 2013) disampaikan bahwa krisis yaitu suatu keadaan tak terduga yang ditandai dengan adanya peristiwa mengejutkan dan kejadian tersebut dapat mengancam nilai-nilai penting dan mengharuskan dibuat strategi serta dibuat keputusan dalam waktu singkat.

Kategori krisis dan dampaknya menurut (Nova, 2011):

1. Krisis level 1: dampak yang ditimbulkan dari krisis ini adalah tercemarnya nama baik organisasi serta adanya hambatan dalam mewujudkan visi dan misi perusahaan;

2. Krisis level 2: dampak yang ditimbulkan dari krisis ini adalah adanya cedera fisik, kemungkinan terjadi korban jiwa, rusaknya property serta hancurnya nama baik perusahaan maupun kombinasinya;

3. Krisis level 3: dampak yang ditimbulkan dari krisis ini mengakibatkan adanya korban jiwa dalam jumlah banyak, kerusakan properti yang terjadi dalam kondisi serius serta organisasi mengalami kemungkinan kebangkrutan.

\section{METODE PENELITIAN}

Penelitian ini dilakukan dengan menggunakan pendekatan kualitatif dengan metode studi kasus. Metode studi kasus menurut Sugiyono (2015) adalah penelitian yang dilaksanakan dengan cara mengeksplorasi lebih mendalam terhadap satu atau lebih terhadap suatu kejadian, proses, program, aktivitas.

Penelitian ini bertujuan untuk mengembangkan dan memberikan sebuah gambaran secara mendalam terhadap objek kajian dengan sifat eksploratif.

Pengumpulan data dilakukan melalui penelitian lapangan dan telaah literatur. Penelitian meliputi observasi, wawancara, dan dokumentasi. Lokasi penelitian di Kantor BPJS ketenagakerjaan Cabang Purwokerto.

Untuk menentukan informan dalam penelitian ini dilakukan secara purposive sampling. Metode pengumpulan data purposive sampling dijelaskan oleh Arikunto (2006) sebagai teknik mengambil sampel yang tidak berdasarkan random, daerah atau strata, melainkan berdasarkan atas adanya pertimbangan yang berfokus pada tujuan tertentu. Adapun kriteria informan adalah pejabat Bidang Pelayanan BPJS Ketenagakerjaan Cabang Purwokerto dan telah aktif minimal 3 tahun dengan alasan dapat membandingkan informasi dan kebijakan yang dilakukan oleh BPJS ketenagakerjaan sebelum dan sesudah pandemi Covid-19 terjadi dan informan lain yang berasal dari peserta BPJS Ketenagakerjaan. 


\section{HASIL DAN PEMBAHASAN}

\section{Permasalahan BPJS Ketenagakerjaan akibat pandemi Covid-19}

Pandemi Covid-19 telah memberikan dampak negatif bagi perekonomian Indonesia, khususnya pada dunia usaha, sehingga banyak pemberi kerja yang terpaksa harus memberhentikan tenaga kerjanya. Kondisi ini mempunyai dampak yang luar biasa bagi lembaga BPJS Ketenagakerjaan baik secara eksternal dan internal yaitu :

1. Pengambilan JHT dalam jumlah yang sangat besar dan dalam tempo singkat, dalam waktu yang hampir bersamaan akan mengakibatkan pengaruh pada dana kelolaan dari sisi aktuaria keuangan yang akan berpotensi menurunnya ketahanan dana. Dalam mengelola dana peserta, BPJS Ketenagakerjaan telah menempatkan dana tersebut dalam bentuk instrumen investasi (saham, obligasi, portofolio, reksadana) dan tata cara pengambilannya mempunyai ketentuan, dana tersebut tidak dapat begitu saja diambil atau dijadikan dana segar, sehingga dibutuhkan kebijakan-kebijakan khusus yang melibatkan pihak-pihak terkait termasuk pemerintah.

2. Bersamaan dengan kondisi tersebut muncul kekuatiran dan tuntutan dari peserta serta beberapa pihak (stakeholder) bahwa dana JHT tidak dapat dicairkan, untuk itu BPJS Ketenagakerjaan harus membuat langkah-langkah dan strategi komunikasi organisasi yang tepat dalam menjelaskan serta meyakinkan kepada peserta dan semua unsur bahwa dana JHT peserta aman dan dapat dicairkan (Syamsir et al., 2019).

3. Untuk menyelesaikan klaim JHT yang begitu meledak, BPJS Ketenagakerjaan harus membuat suatu sistem baru sebagai solusi untuk dapat menyelesaikan hal tersebut. Sistem ini membutuhkan teknologi informasi yang handal dan harus mudah digunakan oleh seluruh peserta yang tidak semuanya paham tentang teknologi (Agostino et al., 2020).

4. Selain itu hal ini menjadi dampak yang luar biasa di internal BPJS Ketenagakerjaan karena harus merubah pola kerja yang membutuhkan petunjuk teknis penyesuaian program baru yang diterapkan secara mendadak sehingga ada pembaruan jobdesk dan perubahan struktur organisasi (Johnston et al., 2012).

Sesuai dengan kondisi tersebut di atas, yang terjadi di BPJS Ketenagakerjaan termasuk dalam kategori Krisis level 2, yaitu :

1. Krisis yang berdampak pada gangguan kesehatan dan psikologis karyawan. Dengan banyaknya klaim menyebabkan volume pekerjaan meningkat yang mengharuskan karyawan bekerja lembur secara terus menerus, di sisi lain BPJS Ketenagakerjaan sebagai badan layanan publik, dituntut untuk memberikan layanan yang terbaik dan mengedepankan kepuasan pelanggan dengan penuh keramahan dan senyuman (Nugraha, 2018).

2. Dengan banyaknya pengajuan klaim sehingga terjadi penumpukan massa yang tidak dapat tertampung di ruang layanan sehingga menimbulkan keresahan dan berpotensi pengrusakan property.

3. Pada masa pandemi, banyak kebijakan pemerintah yang mengharuskan social distancing, tidak diperbolehkan penumpukan massa di suatu tempat, sehingga dengan adanya kerumunan di luar kendali BPJS Ketenagakerjaan, kondisi ini berakibat hancurnya nama baik BPJS Ketenagakerjaan, seolah - olah mengabaikan seruan dan tidak mendukung program pemerintah. 
Gambar 1. Ilustrasi Lonjakan PHK yang mengajukan klaim JHT

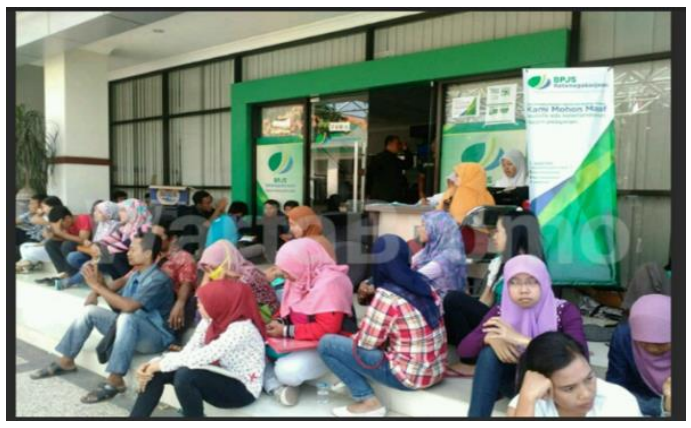

BPJS Ketenagakerjaan dalam memberikan layanan di masa pandemi Covid-19 kepada peserta menggunakan aplikasi LAPAK ASIK secara online dan onsite (offline).

1. Layanan Online

BPJS Ketenagakerjaan tetap berupaya memberikan pelayanan prima kepada peserta. dengan menyediakan kanal pengajuan klaim yang dapat digunakan oleh peserta melalui aplikasi Layanan Tanpa Kontak Fisik (LAPAK ASIK) secara online, sistem ini sangat membantu peserta di masa pandemi karena dapat dilakukan dari manapun dan dapat memilih kantor cabang yang sesuai dengan keinginannya, kemudian dengan sistem online dapat meminimalisir terjadinya penularan Covid-19 karena tidak bertemu secara langsung. Selain itu dengan melakukan klaim secara online menghindari adanya praktik percaloan dan pungutan liar dari pihak-pihak yang tidak bertanggung jawab (Ardiyanti, 2020).

2. Layanan Onsite (offline)

Sistem ini dilakukan dalam rangka menyikapi adanya kendala teknis di lapangan berkaitan dengan layanan online(Rugian et al., n.d.). Tenaga kerja dapat dilayani secara langsung di kantor cabang BPJAMSOSTEK dengan tetap mengedepankan protokol kesehatan. Kantor cabang BPJAMSOSTEK menyediakan sekat yang dilengkapi dengan layar monitor yang terhubung dengan petugas dengan metode video conference untuk kebutuhan dalam berkomunikasi dan melakukan verifikasi data. Untuk menjaga keselamatan bersama, BPJS Ketenagakerjaan menerapkan standar protokol kesehatan pencegahan Covid 19. Sebagai upaya untuk menyelesaikan klaim dalam waktu cepat digunakan layanan One to Many adalah suatu hubungan yang menyatakan terkait satu untuk beberapa entitas menurut Simarmata (2008) yaitu petugas Customer Service Officer (CSO) dapat melayani 4 -6 orang peserta dalam waktu yang bersamaan. Dengan metode One To Many, kemampuan yang dihasilkan atau produksi untuk menyelesaikan klaim menjadi meningkat menjadi lima kali lipat dan physical distancing tetap terjaga. Dan hal ini sudah diimplementasikan oleh BPJS Ketenagakerjaan seluruh Indonesia.

Gambar 2. Ilustrasi pelayanan One To Many

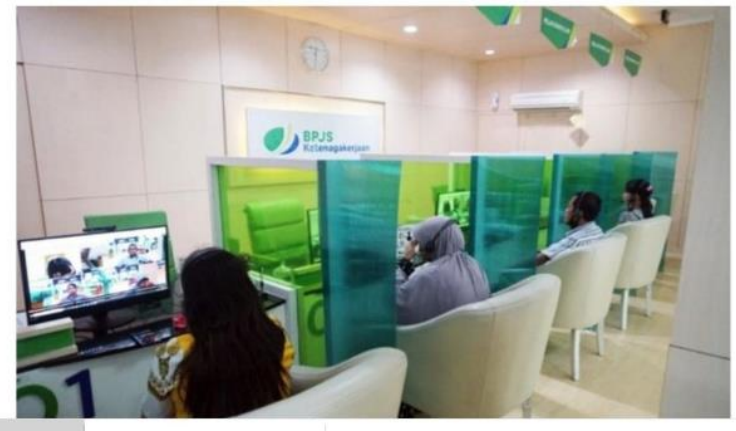


Bagi perusahaan yang terdampak pandemi Covid-19 sehingga melakukan PHK kepada karyawannya, BPJAMSOSTEK memberikan kemudahan klaim dengan cara kolektif. Fasilitas ini diharapkan pihak perusahaan dapat mengakomodir klaim seluruh karyawan dan menunjuk satu orang perwakilan sebagai koordinator.

Dengan adanya pandemi dan melonjaknya peserta yang mengambil JHT maka menjadi peluang bagi BPJS Ketenagakerjaan untuk membuat terobosan melalui layanan LAPAK ASIK. Sejak diberlakukannya protokol LAPAK ASIK dan layanan One to Many, BPJAMSOSTEK mengkonfirmasi adanya peningkatan jumlah peserta yang telah mendapatkan pelayanan. Jika sebelumnya yaitu pada masa-masa normal jumlah peserta yang dilayani sebanyak 8.000 orang per hari, dengan metode ini penyelesaian klaim rata-rata mencapai 15.000 orang per hari, bahkan pada tanggal 2 Juli 2020 klaim mencapai lebih dari 16.800 orang per hari di seluruh Indonesia. Hal ini karena adanya peningkatan kapasitas, baik dari segi infrastruktur Teknologi informatika (TI) maupun kesigapan personil yang bertugas di bagian Customer Service. Dengan kondisi tersebut pemerintah semakin percaya terhadap pengelolaan data BPJS Ketenagakerjaan sehingga pemerintah menjadikan BPJS Ketenagakerjaan sebagai salah satu sumber data yang valid untuk menyalurkan dana Bantuan Subsidi Upah (BSU) kepada tenaga kerja di era pandemi pada Bulan Agustus 2020.

\section{Hasil wawancara Informan}

Hasil wawancara dengan Indah Prihatini selaku Kepala Bidang Pelayanan BPJS Ketenagakerjaan Purwokerto, memaparkan tentang keuntungan/ manfaat penggunaan Aplikasi LAPAK ASIK :

1. Aplikasi ini sangat membantu dalam pelayanan BPJS Ketenagakerjaan kepada peserta di masa pandemi karena merupakan solusi pengajuan klaim secara online sehingga peserta dan petugas tidak bertemu tanpa kontak fisik, pengajuan klaim dapat dilakukan di mana pun dan kapan pun.

2. Pemerataan layanan BPJS Ketenagakerjaan di seluruh Indonesia, karena antrian online ditujukan kepada seluruh cabang BPJS Ketenagakerjaan yang ada di Indonesia sehingga pelayanan pengajuan klaim terbagi secara acak menurut system.

3. Meminimalisir terjadi praktik percaloan atau pihak-pihak yang tidak bertanggung jawab.

Selain wawancara dengan Indah prihatini wawancara juga dilakukan dengan 2 peserta BPJAMSOSTEK. Dalam wawancara dengan informan pertama diakui bahwa proses pelayanan melalui program LAPAK ASIK ini, tidak memiliki kendala atau lancar dan pelayanan yang diberikan oleh petugas BPJS Ketenagakerjaan sangat optimal. Informan pertama tersebut mengapresiasi proses pelayanan yang super cepat dan dinilai sangat baik. Informan menyampaikan bahwa ia tidak perlu repot untuk meluangkan waktu khusus dan datang ke kantor BPJS Ketenagakerjaan cukup mengajukan klaim dari rumah.

Sependapat dengan Informan kedua menuturkan bahwa program LAPAK ASIK sangat membantu bagi peserta untuk mendapatkan pelayanan karena tanpa harus berdesakan mengantri dengan peserta lain dan dia menambahkan bahwa LAPAK ASIK dapat menghemat waktu dan tenaga. Menurutnya, terobosan ini sangat luar biasa dan program pelayanan LAPAK ASIK dapat membantu pemerintah untuk memutus mata rantai penyebaran Covid-19. Dan dia juga menambahkan, bahwa LAPAK ASIK memang sesuai dengan namanya merupakan program yang asik dan memberikan kemanfaatan yang luar biasa bagi peserta dan stakeholder.

Seiring dengan berjalannya waktu, Aplikasi LAPAK ASIK mampu menyelesaikan permasalah pelayanan klaim di masa pandemi dan sesuai dengan kondisi sekarang bahwa pengajuan klaim sudah terkendali serta berangsur angsur berjalan normal sehingga proses layanan dengan metode One to many tidak dilakukan lagi sejak Februari 2021.

\section{KESIMPULAN}

Berdasarkan hasil dan pembahasan dapat disimpulkan bahwa permasalahan di perusahaan atau organisasi harus segera direspon. Bentuk respon yang dilakukan oleh BPJS 
Ketenagakerjaan berupa: Pertama menguatkan kinerja tim, membuat inovasi untuk menghadapi permasalahan yang terjadi dan berkomitmen memberikan pelayanan prima kepada peserta. Kedua adalah inovasi pelayanan disesuaikan dengan kondisi yang ada dan yang Ketiga melakukan monitoring serta evaluasi terhadap tingkat kepuasan pelanggan pada aplikasi $e$ Survey dan kanal Whistle Blowing System (WBS). BPJS Ketenagakerjaan senantiasa melakukan perbaikan secara berkesinambungan di segala aspek layanan untuk mencapai budaya "Service Excellence" atau Pelayanan Prima.

\section{DAFTAR PUSTAKA}

Agostino, D., Arnaboldi, M., \& Lema, M. D. (2020). New development: COVID-19 as an accelerator of digital transformation in public service delivery. Public Money and Management. https://doi.org/10.1080/09540962.2020.1764206

Ardianto, E. (2013). Handbook of Public Relations: Pengantar Komprehensif. Simbiosa Rekatama Media.

Ardiyanti, H. (2020). Komunikasi Media Yang Efektif Pada Pandemi Covid-19. INFO Singkat: KAJIAN SINGKAT TERHADAP ISU AKTUAL DAN STRATEGIS DPR RI, Vol. XII(7), 25-30.

Cangara, H. (2017). Perencanaan dan Strategi Komunikasi. In Jakarta: PT Rajagrafindo Persada.

Gitiyarko, V. (2020). Upaya dan Kebijakan Pemerintah Indonesia Menangani Covid-19. Kompas. https://kompaspedia.kompas.id/baca/paparan-topik/upaya-dan-kebijakan-pemerintahindonesia-menangani-pandemi-covid-19

Johnston, R., Clark, G., \& Shulver, M. (2012). Service Operations Management: Improving Service Delivery. In Service Operations Management.

Maulana, F. L., \& A Leony. (2020, October 30). Gelombang PHK berlanjut, klaim JHT melonjak. https://lokadata.id/artikel/gelombang-phk-masih-terjadi-jumlah-klaim-jht-melonjak

Nova, F. (2011). Crisis Public Relations. Rajawali Pers.

Nugraha, J. T. (2018). E-Government Dan Pelayanan Publik (Studi Tentang Elemen Sukses Pengembangan E-Government Di Pemerintah Kabupaten Sleman). Jurnal Komunikasi Dan Kajian Media, 2(1).

Priharto, S. (2020, July 1). Pelayanan Prima: Pengertian dan Cara Menghadirkannya dalam Bisnis. https://accurate.id/marketing-manajemen/pengertian-pelayanan-prima

Rugian, V., Kawengian, D. D. V, Harilama, S. H., Sam, U., Manado, R., \& Bahu, K. (n.d.). KELURAHAN MADIDIR UNET DI MASA PANDEMI PADA MASYARAKAT. 1-9.

Simarmata, J. (2008). Perancangan Basis Data. In Penerbit Andi, Yogyakarta.

Sugiyono. (2015). Metode Penelitian dan Pengembangan Pendekatan Kualitatif, Kuantitatif, dan R\&D. Metode Penelitian Dan Pengembangan Pendekatan Kualitatif, Kuantitatif, Dan R\&D.

Suharsimi, A. (2006). Prosedur penelitian suatu pendekatan praktik. Jakarta: Rineka Cipta.

Suyadi, I., \& Sunarti. (2016). Pengaruh Sosialisasi Perpajakan, Sanksi Administrasi dan Tingkat Pemahaman Wajib Pajak terhadap Kepatuhan Wajib Pajak Orang Pribadi dalam Memenuhi Kewajibannya (Studi PPh Pasal 21 pada KPP Pratama Singsosari). Jurnal Perpajakan, 8(1).

Suyanto, A., \& Sutopo. (2006). Pelayanan Prima. Jakarta: Lembaga Adminisstrasi Negara. 
Syamsir, A., Nur, M. I., Wahidah, I., \& Alia, S. (2019). Kualitas Pelayanan Publik Dalam Pembelajaran Berbasis Daring di Tengah Pandemi Coronavirus Disease 2019. Sosial Dan Budaya, 1(1), 1-12.

Yunus, N. R., \& Rezki, A. (2020). Kebijakan Pemberlakuan Lock Down Sebagai Antisipasi Penyebaran Corona Virus Covid-19. SALAM: Jurnal Sosial Dan Budaya Syar-I, 7(3). https://doi.org/10.15408/sjsbs.v7i3.15083

https://www.bpjsketenagakerjaan.go.id/berita/26699/-BPJAMSOSTEK-Bikin-TerobosanLapak-Asik,-Begini-Pengakuan-Penerima-Manfaatnya

https://www.bpjsketenagakerjaan.go.id/berita/26920/Top--Layanan-One-To-ManyBPJAMSOSTEK-Mampu-Layani-16.000-Orang-per-Hari 